\title{
Analysis of Major Environmental, Motivational and Attitudinal Factors Affecting EFL Learning - Teaching Situations (Correlations \& Educ. Implications)
}

\section{By}

Tariq Mohammad Al-Ghonaimy (Ph.D. U.K.)

مجلة الدراسات التريوية والانسانية ـ كلية التربية ـ جامعة دمنهور

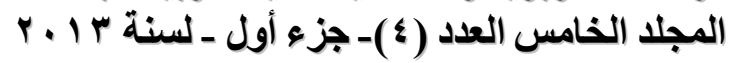




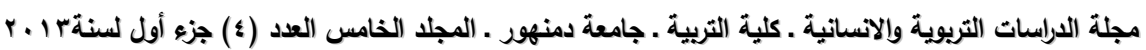

\section{Analysis of Major Environmental, Motivational and} Attitudinal Factors Affecting EFL Learning -Teaching Situations (Correlations \& Educ. Implications)

\section{Introduction:}

People involved in language teaching often say that students who really want to learn will succeed whatever the circumstances in which they study. As there is a will there is a way. Actually all EFL teachers can think of situations in which certain 'motivated' students do significantly better than their peers. Again the motivation that learners bring into their classes makes them receive higher grades and achieve better proficiency in the target language (Rueda \& Chen, 2005) (Hsieh, 2002) claimed that there is a positive relationship between the learning environment and student motivation. Similarly, Chang \& Shu, (2000) echo Hsieh's idea by stating the following four guiding principles to define an excellent learning environment:

1.A good learning environment helps to improve the learning outcome.

2. A good environment provides the learners with care and support.

3. A good learning environment inspires and boosts the learning spirit.

4. A good learning environment cultivates responsibility in the learner.

- In my own perception, positive motivation and effective attitudes can relatively compensate for poor teaching learning processes and not vice versa. It is some kind of internal driving force that encourages or stir somebody to pursue a course of action. In this individual works or strives to learn the language because of a desire to do so and the satisfaction experiences in this activity.Gardner(1985). Gardner here links the learner's motivation to his reason for learning the language. He refers to this as the learner's orientation. He and Harmer, $\leqslant 10$ 
J.(1991) identified two main categories of distinct orientations for learning a language: extrinsic motivation which is concerned with factors outside the classroom, and intrinsic motivation, which is concerned with factors inside the classroom.

Similarly, it has been suggested that there are two main types of motivation: integrative motivation and instrumental motivation:

\section{a) Integrative motivation:}

This kind of motivation students need to be attracted by the culture of the target language community, and in the strong form of integrative motivation they wish to integrate and affiliate themselves into that culture.

\section{b) Instrumental motivation:}

It is meant to describe a situation in which students believe that mastery of the target language will be instrumental for utilitarian purposes such as getting better job, or a higher salary, position or status. The language is instrumental in their attainment of such a goal.

The fact remains that both integrative and instrumental motivation may lead to success, but the lack of either may bring about problems(Alvyda and Metiuniene, 2006; Borwn, 1987; Ellis, 1985).

According to Gardner (1985), integrativeness reflects a genuine interest in learning the target language in order to be psychologically closer to the target language community; a low level of integrative motivation indicates no interest in learning the target language whereas a high level would indicate strong interest. In addition, Crooks and Schmidt (1991) argue that the empirical evidence is not clear enough to support integrative motivation is a cause and second language achievement is the effect.

Again, the bad impact of poor environment and the lack of authentic learning materials would lead to low learning proficiency of learners as mentioned by Chang(1999) and Clement (1986). 
Numerous definitions of the environmental factors center around the learner while undergoing the process of learning. Smith, Neisworth, and Greer(1978)defined the environmental factors affecting the learning process as having five aspects:

1.Physical environment, architecture, design, and arrangement for the school and particularly the instructional space.

2. Instructional arrangement, curriculum content and characteristics, teaching method and materials and media for instruction.

3. Social situation, teacher - child, child - child interaction, group dynamics, classroom, school, and community social aspects.

4. Evaluation instruments and evaluative practice, placement, summative, and formative devices and procedures used by school psychologists and others.

5. Supportiveservices,in-school(health-speech, counseling) and out - of - school(employment counseling, follow -up) facilities.

Plainly, the contextual factors are of paramount importance that are the classroom conditions. Various studies (Clément, Dörnyei \& Noels, 1994; Olshtain, Shohamy, Kemp. \& Chatow, 1990; Pintrich, Roeser \& De Croot, 1994) have found that teacher attitudes, teaching styles, materials, means of assessment, individual vs. group work and other classroom context effects influence not only achievement, but also aspects of motivation, including goal orientation, selfefficiency, task value and mastery vs. performance orientations.

Gardener and Lambert (1972) were the pioneers to maintain the learners' success in acquiring a second language with the presence of motivational variables known as integrative and instrumental. Krashen (1981) defined the learners' type of integrative motivation as the learners' desire 
to be valued as a speaking member of the second language community. As for the instrumental orientation motivation, Krashen (1981) clarified it as the learner's desire to achieve proficiency in the language for utilitarian or practical purposes which will encourage its performers to interact with the second language speakers so as to achieve certain ends.

Dornyei (1994) pointed out that while intrinsic motivation is potentially a central motivator of the educational process students exposed to external reward or punishment may lose their intrinsic motivation, negatively affecting performance and outcome. Plainly, like integrative and instrumental motivation, intrinsic and extrinsic motivation orientations do not exist in mutual exclusivity, but rather on a continuum that Dörnyei (2001) has divided into five categories;

1.External Regulation - The motivation comes strictly from outside sources, from reward to avoidance of punishment.

2. Interjected Regulation - The following of imposed rules in order to avoid the feeling of guilt.

3. Identified Regulation - An individual participates in activity because of the perceived usefulness of doing so.

4. Integrated Regulation - Behaviours are made by choice and are based on an individual's needs, values, and identities.

5.Intrinsic motivation - An individual engages in an activity simply for the sake of the activity itself.

Actually as one moves from 1 to 5 in the above continuum there is a shift of Dörnyei's of control from external to internal. As students progress, Liuoliene and Metiuniene (2006) investigated the relationship between the student's motivation, attitude, and level of responsibility. It was found that there exited a statistically significant correlation between learners' motivation and sense of responsibility(Liuoliene and Metiumiene, 2006). Additionally, students with higher levels of learning motivation expressed a greater need to study autonomously. The relationship between the focus of control 
and motivation is well - depicted in the use of the phrase 'An ear for language' (Sturgeon, 2008).

Six factors were selected among others by Oxford and Shearin (1994). Language learning motivation can be affected by them, they are:

-Attitude.

-Beliefs about one's self.

-Goals.

-Involvement.

-Environmental support.

-Personal attributes.

Alansari (2000) conducted a study and demonstrated that the results had no significant association between the motivational variables and students' academic success in English.

Alansari and Lori (1999) showed that environmental factors, such as parental support and encouragement may have a particularly strong motivational impact of English learners, when compared with other student groups. Obeidat (2005) surveyed Iranian undergraduate students and found that they exhibited high levels of both instructional and integrative motivational orientation.

Kormos and Dörnyei (2004) found that positive course attitudes are able to compensate for students dislike are able to compensate for students dislike towards a particular learning task but that motivation was a predictor of the level of engagement in their tasks, and not necessarily of the outcome. Moss and Ross-Feldman (2003), (2004) advocate the use of task-based language teaching in order to help increase motivation and improve second language acquisition, as they promote learner-learner involvement. In this way, group atmosphere can improve and can help instructors to pair more motivated learners with those that are less motivated which can be very beneficial during certain language tasks. 
Thanasoulas (2002) supported the notion of creating realistic learners' beliefs by helping them to be aware of the learning process via providing them with opportunities for reflection which can work well with the higher-cognitively functing adult learner population. Next, they can explore which tasks and materials work best for them.

In this way students who set goals for themselves will fill a greater sense of control over their language learning which will, in turn, work as a protector of increase motivation and they will become more sensitive to their individual learning needs and preferences (Kubanyiova, 2006).

There has been a number of studies which examined the learner's motivation and attitudes towards the target language in contexts where that language being learned is the dominat, as the case with French in some Canadian territories English in the United States of America. Gardner and Lambert (1972) conducted a study to determine the importance of motivational variables on second language acquisition. The subjects were 43 English-speaking high school students. All the subjects had a seven year training in French. The results of those two researchers found that integrative motivation was a major contributor to the study of French. This led them to assume that learners with high integrative motivation learn faster than their counterparts who are not integratively motivated.

Spolsky (1969) compared the attitudes of 325 foreign students who represented 80 different countries. They were asked to rate the importance of 14 statements which describe personal reasons for coming to the United States. The findings indicated that integrative motivation was an important factor for second language acquisition. However, other subjects were instrumentally motivated to come to the Unites States.

Oller et al.(1977) investigated the significance of attitudinal and motivational variables to second language 
acquisition. Findings showed that integrative motivation was a major factor in the subjects' acquisition of English.

Svanes (1987) conducted a study to investigate the influence of motivation on the acquisition of second language by foreign students at the University of Bergen, Norway, and the relationship between variables and cultural distance. Results showed that students from Europe and America were found to be more integratively motivated than students from the Middle East, Africa and Asia who were instrumentally motivated. There was also a weak positive correlation between integrative motivation and language proficiency.

Gardner and Maclntyre (1991) ex investigated the effect of integrative motivation and instrumental motivation on the learning of French / English vocabulary. Results showed that both integrative and instrumental motivation facilitated English vocabulary learning. In addition, subjects with higher levels of integrative motivation learned more words overall than did subjects with low levels, and those who anticipated possible financial reward learned more than those who didn't. The purpose of the study:

The purpose of this study were threefold:

1.To identify, describe and analyse three different variables (environmental, motivational - attitudinal) affecting the EFL learning process of two Egyptian universities.

2. To investigate (a) the relation between each of these variables and the level of attainment in English of the EFL students and (b) the correlation coefficient between Commulative Grade Point Average (CGPA) and EFL learners' English proficiency.

3. To suggest some general pedagogical implications that might enhance the EFL learning process. 


\section{The problem of the study:}

Learning environment aspects surrounding EFL learners are vital and decisive. They are, sometimes the key issue which shape the attitudes and motivation of learners.

It is a fact that is supported by numerous researches findings stating that EFL learners are utilitarian. That is, they learn English to meet certain job-related needs. (Metiuniene, 2006; Dörnyei, 1994; Liuoliene, 2006; Al-Dossari, 1999). EFL learners may be instrumentally and / or integratively motivated in their study of English. Students' motivation and attitudes are considered by many researchers to be essential contributors to the success or failure of the language learning process (Gardner and Lysynchuk, 1990; Gardner and Macltyre, 1993). In addition, good environmental factors are helpful in motivating or demotivating EFL learners. So three internal circles are closely connected and each of which has its own role in the learning-teaching process.

\section{Research Questions:}

The following research questions were addressed:

1. What is the role of some major environmental factors in the EFL students' learning-teaching situation?

2. What is the EFL students' motivational factors for learning English?

3. What are the attitude factors of EFL students towards learning English?

\section{Materials:}

A) A five-point Likert scale questionnaire ranging from 'Strongly Agree' to 'Strong Disagree' was used. A Special place was left blank next to Agree for recording any special remarks by participants.

Having reviewed several related studies including questionnaires, and after numerous processes of selection, modification and adaptation of those questionnaires, a new questionnaire was generated with the author's personal experience in the field. 
The purpose of the 30-items questionnaire of this study aimed at determining the environmental, motivational (integrative \& instrumental) and attitudinal factor affecting EFL learning.

The four main components of the questionnaire covered the following components:

1.Environmental factors affecting EFL learning.

2.Integrative motivation factors affecting EFL learning.

3.Instrumental motivation factors affecting EFL learning.

4.Attitudinal factors affecting EFL learning.

B) Amultiple- choice proficiency test designed by the researcher and other four specialists in ELT. The test incorporated reading, writing composition, grammar and a close test.

\section{Environmental factors items:}

EFL students were asked to rank the first 6 statements in the questionnaire to their relevance to them personally. The higher the scores will be, the more they will be described as confronting difficult unhelpful factors in their learning English as a foreign language.

\section{Instrumental Orientation:}

This section assessed the extent to which the EFL students perceive utilitarian reasons for studying English. The EFL students have to rate on a five-point scale the extent to which each of the seven instrument reasons (7-13)for learning English was descriptive of his/her feelings.

\section{Integrative motivation:}

This section in the questionnaire assessed the extent to which EFL students believe that learning English as a foreign language is important to help them interact and share cultural experiences with the English speaking community. The EFL students were asked to rate on a five-point scale the extent to which each of the six integrative reasons (14-19) for learning English which were descriptive of his / her feelings. 
In case EFL students place more emphasis on the integrative value of learning English as a foreign language, they will be considered as integratively motivated in their learning of English. Thus the higher the EFL students' score on this measure are, the more they will be identified as being integratively oriented.

\section{Attitudinal factors:}

ESL students were asked to indicate their agreement or disagreement with the benefits of English language learning. They were asked to respond to eleven items worded from no. 20 to 30 about the value of learning of English as a foreign language.

\section{Proficiency Measures:}

The students' responses to the 30 items on the questionnaire were correlated with scores obtained from a program-neutral proficiency test. This incorporated the following components:

A) A multiple choice reading test;

B)A multiple choice grammar and usage test;

C) A free composition doubled marked by two EFL specialists;

D) A close test in the standard format from reading, with a passage gapped at fifths.

\section{Participants:}

186 subjects participated in this study, randomly selected from two Egyptian universities third and fourth year from two faculties of education in Kafrel-Shekh and Damanhour, majoring in English department.

\begin{tabular}{|l|l|l|l|}
\cline { 2 - 3 } \multicolumn{2}{c|}{} & Year & \multicolumn{1}{c}{} \\
\hline Area & Third & Fourth & \multirow{2}{*}{186} \\
\hline Kafrel-Shekh & 42 & 29 & 54 \\
\hline Damanhour & 61 & 83 & 186 \\
\hline Total & 103 & 54 &
\end{tabular}

Data Collection and Statistical Analysis: 
The data collection process tookplace in two different settings in Egypt as mentioned earlier; Kafrel Sheikh and Damanhour. Four days were chosen in order to administer the questionnaire in each area as well as the proficiency English test.

For analysis of data, the SPSS (Statistical Package for Social Sciences) was used.

The EFL learners' responses to the questionnaire items were coded as follows: 'Strongly agree' $=5$, 'Agree' $=4$, 'Undecided'= 3, 'Strongly Disagree' $=2$, 'Disagree' $=1$.

a) Results of EFL Learners' concerning environmental factors affecting EFL learning.

Table (1) displays the EFL learner's responses in percentage to the questionnaire items related to environmental factors they may encounter during EFL learning.

\section{Table (1): environmental factors affecting EFL learning}

1) College / school condition (buildings,lights, ventilation, libraries, sizes, books... etc) are helpful to EFL learning-teaching situations.

2) Local educational governorates, EFL supervisors, EFL in-service training and pre-service training are helpful.

3) Mingling with English speaking bodies (tourists centers, mutual visits, availability to listening to authentic English, having an access to computer services and watching understandable enjoyable English movies) are within reach.

4) Parents, relative and friends have an effective role on my English study (e.g. encouragement, mutual talks in English, and audiovisual technological aids).

\begin{tabular}{|l|l|l|l|l|}
\hline SA & A & LIN & SD & D \\
\hline $5.3 \%$ & 2.6 & 4.3 & 47 & 39.7 \\
\hline $29 \%$ & 18.8 & 12.9 & 21.5 & 17.7 \\
\hline $37.6 \%$ & 33.3 & 8.6 & 12.9 & 7.5 \\
\hline $18.2 \%$ & 43 & 20.9 & 11.8 & 5.3 \\
\hline
\end{tabular}




\begin{tabular}{|l|l|l|l|l|l|}
\hline $\begin{array}{l}\text { 5) My family supports me } \\
\text { financially to study EFL } \\
\text { resourcefully (e.g. private tuition, } \\
\text { buying English tapes and up-to- } \\
\text { date courses (e.g. at British } \\
\text { Council, B.B.C. centers, and } \\
\text { American Centers). }\end{array}$ & $33.8 \%$ & 49 & 6.4 & 5.9 & 4.8 \\
\hline $\begin{array}{l}\text { 6) English private tuition teaching } \\
\text { staff are better providers to EFL } \\
\text { teaching. }\end{array}$ & $26.2 \%$ & 38.1 & 18.8 & 11.2 & 4.8 \\
\hline
\end{tabular}

Generally, the environmental factors such as college conditions (buildings, ventilation, teaching aids, language labs.,) $87.7 \%$ and parental support and encouragement educationally and financially(82.8\%) were the highest percentages to affect EFL learning negatively as perceived by EFL learners.

But mingling with native English speakers or having an access with them via internet chat was agreed upon by $70 \%$ of EFL participants and $43 \%$ of them remarked that they wished they had had more opportunities to have face to face interaction with native speakers. As private tuition was not available for all EFL learners, more than half of the participants $64 \%$ s remarked that there was a difference between the quality of teaching outside colleges (private tuition) and university lectures.

It is worth remarking here that the majority of respondents (over 77\%) observed that many lecturing staff hare no enough time to do their jobs effectively and they attributed that deficiencies to the fact that the lecturing staff are so busy people as they are involved in teaching in more than one college on the same day. That seems to minimize the benefit of teachings effectively and resourcefully.

It was also observed that most of the EFL teaching staff have no adequate staff rooms and office hours for helping EFL learners academically and socially.

b) Results of EFL learners pertaining to integrative motivation: 
Table (2) displays the EFL learners' responses in percentage to the questionnaire items relating to integrative motivation they may have towards the learning of English as a foreign languages.

Table (2): integrative motivation affecting EFL learning

\begin{tabular}{|l|l|l|l|l|l|}
\hline Items & SA\% & A\% & LIN\% & SD $\%$ & D \\
\hline $\begin{array}{l}\text { 1) I learn English because } \\
\text { it enables me to meet, talk } \\
\text { and communicate with }\end{array}$ & $\begin{array}{l}26.3 \% \\
\text { those who speak it. }\end{array}$ & $\begin{array}{l}20.9 \\
39\end{array}$ & $\begin{array}{l}6.4 \\
12\end{array}$ & $\begin{array}{l}24.1 \\
45\end{array}$ & 22 \\
\hline $\begin{array}{l}\text { 2) I learn E. because it } \\
\text { enables me to think and } \\
\text { behave like those who } \\
\text { speak it. }\end{array}$ & $87.8 \%$ & 29.5 & 2.6 & 10.7 & 9.1 \\
\hline $\begin{array}{l}\text { 3) I learn E. because it is } \\
\text { the major language used } \\
\text { in communication among } \\
\text { world's nations. }\end{array}$ & $50 \%$ & 41.4 & 5.3 & 2.6 & 0.5 \\
\hline $\begin{array}{l}\text { 4) I learn E. because it } \\
\text { enables me to recognize } \\
\text { the lifestyles of those who } \\
\text { speak it. }\end{array}$ & $77.2 \%$ & 32.7 & 21.5 & 22.5 & 5.9 \\
\hline $\begin{array}{l}\text { 5) I learn E. because it } \\
\text { facilitates the process of } \\
\text { acquiring friends among } \\
\text { English natives. }\end{array}$ & $23.1 \%$ & 45.6 & 14.5 & 11.8 & 4.8 \\
\hline $\begin{array}{l}\text { 6) I learn E. because it } \\
\text { enables me to recognize } \\
\text { the people who speak it } \\
\text { and their social tradition } \\
\text { via movies and English } \\
\text { programmers. }\end{array}$ & $25.8 \%$ & 40.8 & 16.6 & 8.6 & 8.6 \\
\hline
\end{tabular}

From table (2) it can be noticed that more than half of the EFL learners (77.3\%) said that they are learning English in the hope that it enables them to think and behave like those who speak it as their first language. Nearly $47.2 \%$ of the participants observed that they are learning English (linguistics and literature) in the hope that this would enable them to communicate with those who speak it. Similarly, a largest proportion of responses (91.4\%) said that they learn 
English because they are aware of the pioneering role of English as the major international language used in communication among the world's nations nearly in every aspect of life.

Recognizing the lifestyle of English natives, watching English movies and benefiting from English programs such as (B.B.C, Special English...), and acquiring friends were the motivation behind learning English by nearly $65 \%$ of the EFL responants.

c) Results pertaining to instrumental motivation:

Table (3) displays the EFL learners' responses in percentages to the questionnaire items relating to instrumental motivation they may have towards learning English as a foreign language.

Table (3) :integrative motivation affecting EFL learning

\begin{tabular}{|l|l|l|l|l|l|}
\hline Items & SA & A & LIN & SD & D \\
\hline $\begin{array}{l}\text { 1) I learn English because it helps } \\
\text { me perform my job successfully. }\end{array}$ & $45.1 \%$ & 33.8 & 6.4 & 9.1 & 5.3 \\
\hline $\begin{array}{l}\text { 2) I learn English because I do not } \\
\text { consider the individual educated } \\
\text { and cultured unless he has the } \\
\text { capacity to communicate in } \\
\text { English. }\end{array}$ & $20.9 \%$ & 33.8 & 9.6 & 27.9 & 6.9 \\
\hline $\begin{array}{l}\text { 3) I learn English because it is } \\
\text { socially plausible for the individual } \\
\text { to learn a foreign language in } \\
\text { addition to his mother tongue. }\end{array}$ & $38.7 \%$ & 42.4 & 5.9 & 7.5 & 5.3 \\
\hline $\begin{array}{l}\text { 4) I learn English because it helps } \\
\text { me to guarantee a better prestigious } \\
\text { social status and a well-pay source } \\
\text { anywhere. }\end{array}$ & $53.3 \%$ & 31.1 & 3.7 & 6.9 & 3.7 \\
\hline $\begin{array}{l}\text { 5) I learn English because it is the } \\
\text { language used currently in the field } \\
\text { of science, technology, diplomacy, } \\
\text { inter net, navigation and higher } \\
\text { studies and English constitutes an } \\
\text { essential portion in both school and } \\
\text { college curriculum. }\end{array}$ & $28.8 \%$ & 36.6 & 17.7 & 11.8 & 6.9 \\
\hline
\end{tabular}

Table (3) shows the EFL learners' responses in percentage to the questionnaire items related to instrumental motivation they may have towards the learning of English as a foreign language. About (84.4\%) of the respondents were 
outspoken enough to disclose that the main driving force for studying English was materialistic in that English language could guarantee a good-pay and a well- prestigious position anywhere in the world. In this respect around $33 \%$ of the EFL learners, actually student-teachers, remarked that they are involved in private tuition to elementary(primary) and preparatory EFL pupils.

To $(81.1 \%)$ of the EFL respondents, English is to be studied as a result of social plausibility for an individual learner to learn English as a foreign language, in addition to his mother tongue (Arabic). More than half of the EFL respondents $(54.7 \%)$ consider an individual uneducated and uncultured if he/she is incapable of communicating in English. In contrast, some EFL respondent (34.8\%) disagreed with this statement. The majority of EFL respondents (78.9\%) indicated that the knowledge of English helps them perform their expected English teaching job effectively. Furthermore, EFL respondents said that they learn English for utilitarian purposes because it is a vital and an essential course in both college and school curriculum and a world's most crucial language in nearly every segment of science, technology, medicine, navigation and higher studies. (65.4\%) while $17.7 \%$ of them remained undecided towards this perception. Only $(18.7 \%)$ surprisingly disagreed with this statement.

d) Results pertaining to attitudinal factors affecting EFL learning.

Table (4) displays the EFL respodants' attitudes towards the learning of English as a foreign language. In general, EFL respondents' attitude is one of the favorability towards learning of English as a foreign language. Positiveness towards learning English by the EFL respondents was perceived by a majority of respondents (75.9\%) who said they like the lecture atmosphere so much if it was run in English only, but that seems to be mainly for the sake of passing the final exam $(89.2 \%)$. But to them, this 
means that they at any rate enjoyed the study of English as a foreign language $(82.7 \%)$ to speak English fluently was an aim voiced by similar to the way English natives do (67.1\%).

A large number of EFL respondents (62.9) said that they wish they could have many English speaking friends, perhaps to improve (as mentioned earlier) their speaking skill. $77.7 \%$ of the EFL respondents said that to study English is regarded as a good aim and will make them more cultured and educated. Around (75.12\%) of them felt that when they miss a lecture they ask their colleges or doctors to know the home assignment. Additionally when they hear a friend using English fluently they (51\%) they wish they could practice English with him/her. (67.1\%) finally that make them feel happy (60.1).

Table (4) :displays Attitudes of EFL Respondents toward learning EFL

\begin{tabular}{|c|c|c|c|c|c|}
\hline $\begin{array}{c}\text { Attitudes towards English Language } \\
\text { Learning ELL }\end{array}$ & SA & A & U & SD & D \\
\hline $\begin{array}{l}\text { 1) Speaking Eng. anywhere makes } \\
\text { me feel happy. }\end{array}$ & $39.2 \%$ & 20.9 & 3.7 & 25.2 & 10.7 \\
\hline $\begin{array}{l}\text { 2) When I hear a student in my class } \\
\text { speaking English well, I like to } \\
\text { practice speaking with him/her. }\end{array}$ & $33.3 \%$ & 17.7 & 6.4 & 26.8 & 15.5 \\
\hline $\begin{array}{l}\text { 3) I like to practice English the way } \\
\text { native speakers do. }\end{array}$ & $43.5 \%$ & 23.6 & 6.4 & 16.6 & 9.6 \\
\hline $\begin{array}{l}\text { 4) I wish I could have many Eng. } \\
\text { speaking friends. }\end{array}$ & $50 \%$ & 12.9 & 9.1 & 10.7 & 13.4 \\
\hline $\begin{array}{l}\text { 5) When I miss a lecture I ask my } \\
\text { friends or teachers for the home } \\
\text { assignment. }\end{array}$ & $60.7 \%$ & 15.05 & 10.7 & 8 & 5.3 \\
\hline $\begin{array}{l}\text { 6) Do not feel enthusiastic to come } \\
\text { to lecture when the English is } \\
\text { being taught. }\end{array}$ & $16.1 \%$ & 20.9 & 4.8 & 38.1 & 19.8 \\
\hline $\begin{array}{l}\text { 7) Studying English will make me } \\
\text { more educated and cultured. }\end{array}$ & $55.3 \%$ & 22.04 & 3.2 & 14.5 & 4.8 \\
\hline $\begin{array}{l}\text { 8) I like my English lecture so } \\
\text { much. }\end{array}$ & $30.1 \%$ & 25.8 & 8.6 & 22.5 & 12.9 \\
\hline $\begin{array}{l}\text { 9) Frankly I study English just to } \\
\text { pass the exams. }\end{array}$ & $47.3 \%$ & 41.9 & 5.9 & 4.3 & 0.5 \\
\hline $\begin{array}{l}\text { 10) I feel proud to study to English } \\
\text { with personal enjoyment. }\end{array}$ & $48.9 \%$ & 33.8 & 3.7 & 10.2 & 3.2 \\
\hline $\begin{array}{l}\text { 11) I wish I could speak English } \\
\text { fluently as a goal. }\end{array}$ & $59.6 \%$ & 16.6 & 2.1 & 14.5 & 6.9 \\
\hline
\end{tabular}




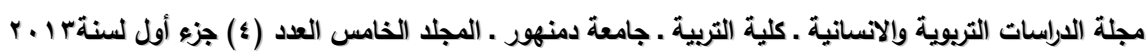

$\longrightarrow$ 
Table (5) correlations between variables

\begin{tabular}{|l|l|l|l|l|l|l|l|}
\hline & Variable & 1 & 2 & 3 & 4 & 5 & 6 \\
\hline 1 & $\begin{array}{c}\text { Proficiency in } \\
\text { EFL }\end{array}$ & - & $0.882^{* *}$ & $0843^{*}$ & 0.815 & 0.659 & 0.140 \\
\hline 2 & Environmental & & - & $0.873^{* *}$ & $0.941^{* *}$ & 0.012 & $0.830^{* *}$ \\
\hline 3 & Motivational & & & - & $0.605^{* *}$ & 0.612 & $0.465^{* *}$ \\
\hline 4 & Instrumental & & & & - & 0.713 & 0.519 \\
\hline 5 & Integrative & & & & & - & $0.524 * *$ \\
\hline 6 & Attitudinal & & & & & & - \\
\hline
\end{tabular}

Correlations between English proficiency and variables:

In addition to the statistical analysis of the EFL students' educational environment, motivation and attitudes, a correlation analysis was conducted to explain the relationship between the valuables. The results are displayed in table (5). The Person Correlation Coefficient and Two-Tailed Test of Significance were used to flag any correlation between the variables under investigation. The analysis of the results displayed a significantly positive correlation between the five variables. Environmental variable was correlated with motivational $(\mathrm{r}=0.873, \mathrm{p}<0.1)$ attitudes towards learning English $(\mathrm{r}=0.830, \mathrm{p}<0.1)$, and instrumental variable $(\mathrm{r}=0.941$, $\mathrm{p}<0.1)$.

English language proficiency of the EFL studentteachers correlated significantly with environmental variable, motivational, instrumental as $(\mathrm{r}=0.882, \mathrm{p}<0.1,0.843, \mathrm{p} .<0.1$, $0.815, \mathrm{p}<0.1)$ respectively. There was a negative correlation between EFL students' English proficiency and their attitudes towards learning English as a foreign language $(r=140$, $\mathrm{p}<0.05)$. Instrumental motivation was correlated with integrative and English proficiency $(\mathrm{r}=0.713, \mathrm{p}<0.1)$. It is important to mention that there was a high significant correlation coefficient between Commulative Grade Point Average (CGPA) and English proficiency of the EFL student $(0.66 \mathrm{p}<0.001)$. 


\section{Discussion:}

The results of the present study on the effects of environmental, integrative and instrumental motivation and attitudinal factors on English learning and the correlations of these variables with English proficiency bear similarities to previous research findings in ESL and EFL contexts (Mallah, 2002; Lui, 2007). Findings of this study disclosed various environmental factors demotivating EFL learners in the EFL teaching process. It appears that the most threatening factor was the poor quality of the EFL college input represented in the very busy teaching staff who seemed to have inadequate and unhelpful time for teaching and meeting EFL respondents. Added to this were the problems encountered pertaining to effective parental encouragement and family level of education. Lack of face to face interaction with English natives was seen as demotivating.

The very poor deplorable state of textbooks, (mainly photocopied) was a crucial factor distancing EFL learners from reading and enjoying the original English text books. What seems to be seen and used are the very poor quality of Handouts, the EFL respondents remarked, as the main source of study in the English depts.

Problems pertaining to the examination system in the English departments worsened the case as being void of the oral aspect of English. They aimed to assess how much they know by heart the content and not how to think or enjoy the language arts by using it. They mainly study the language theoretically not practically.

Being integratively motivated, the EFL learners liked to learn English in the hope that they would think, behave and live as native English do.

Furthermore, the present study of the integrative motivation of the EFL respondents meets with some previous studies (e.g. Gander and Lambert, 1972; Gardner and Macltyre, 1993; Oller, et al. 1977). 
Being instrumentally motivated, the EFL respondents of this study showed a definite degree of agreement that they learn EFL because they wish to perfect their teaching EFL which is a good-pay issue anywhere. Certainly, utilitarian purposes seemed to be the motive power of the study of EFL respondents. Findings of this research meet with previous studies investigated by Liu, 2007; Luckmani, 1972; ALKhatib, 2007; Mallah, 2002; Obeidat, 2005).

With respect to the EFL respondents' attitudes, towards the learning of EFL, they displayed a remarkable degree of positiveness. The findings are consistent with findings in some contexts (e.g. AL-Khatib, 2007; Voget and Oliver, 1999; Mallah, 2000). Their studies concluded that language learners have some definite degree of positiveness towards learning of the target language. Correlational analysis of the results displayed, the EFL respondents' attitudes towards learning English as a foreign language correlated significantly with their motivational orientation and the type of motivation (integrative vs. instrumental). This means that the more the EFL learners are instrumentally and/or integratively motivated to learn English as a foreign language, the more they have positive attitudes towards learning EFL and vice versa. This is consistent with some previous research findings (e.g. Liu, 2007; Mallah, 2002), which reached the same conclusion.

Conclusion and pedagogical implications:

It is a fact that environment, motivation, attitudes and English attainment for non-English speakers are complex social, cultural and sociolinguistic factors. Not so many in EFL area would disagree that EFL students with positive attitudes usually progress more rapidly in English language learning. Plainly, when EFL students have positive attitude, it acts as a motivational impetus to enable a greater effort to achieve the goal of the language learning. It is worth mentioning here that a great number of the EFL respondents reported that to them, English language is only used for 
mainly utilitarian purposes and their efforts to study it focused on decorous targets such as doing assignments, reading handouts, talking to lecturers to score examinations: also, they felt that it is not important for them to master the English language as they believe that it is quite enough if they are able to express themselves in basic language. This could be so as may be attributed that EFL respondents do not need English for daily interaction (ESL) but for utilitarian purposes. Therefore, an integrative orientation may be harder to foster as a vital driving force for learning English among these EFL learners.

The findings of this study also presented a picture which as acertained that the better environmental factors in learning English, the better positive correlation with students' motivation, attitudes and of course, English language proficiency.

One important pedagogical implication is the significance of focusing on communication as a vital component in TEFL through educational helpful environment. This could lead to better EFL Learners capable of having positive attitude towards learning English. Actually poor educational environment would necessarily lead to poor learning outcomes.

English language teachers themselves do need to have positive motivational attitudes. They are responsible for encouraging and enhancing their learners' motivation and attitudes because, according to my experience in TEFL, nothing can motivate learners like success. EFL teachers are required to be sensitive to the EFL class and by using the most suitable English methodological approaches of TEFL. In addition, they shoulder the responsibility of selecting and integrating the English language skills of up-to-date materials and supplementary resources based on real learners needs. Both EFL learners' and teaching staff members' motivation should be complementary to each other. This can capture 
students' attention to learn English successfully. Positive attitudes toward English should be the umbrella under which encouraging helpful educational environment atmosphere pave the way for implementing appropriate TEFL methods and activities. In addition ELT curriculum makers have to reconsider aims, content cognitive domain and design to meet the real interest and needs of EFL learners who really have different perceptions about learning regarding gender, specialization, year of study, etc. Thus, motivation can be regenerated to reshape attitudes, reform poor educational environment and eventually better acceptable English proficiency outcomes. 


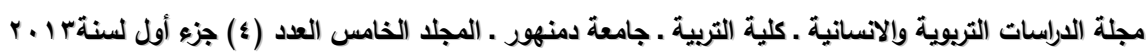

$\longrightarrow$ 


\section{Reference}

1. Al Khatib, M.A. (2007). English in the Workplace: An Analysis of the Communicative Needs of Tourism and Banking Personnel. Asian EFL Journal, 7 (2).

2. Alansari, S. H (2000) motivation and students academic success in learning English as A second language. Journal of education \& psychology 12, (1), 11-37.

3. Alansari, s.\& Lori, A.R (1999) motivation casc A companiative study of two learning group. Journal of saud university (ARTS). Vol.1, 23-38.

4. Alvyda, L. and Metiuniene, R (2006) A study of soudi police officers motivation and attitude www.Alhuqbani.com.

5. Brown, H.D (1987) principles of language learning a teaching Englewood cliffs New Jersy printice- Hall. (2000) op. ut.

6. Chambers, G.N. (1999). Motivating Language Learners. Clevedon: Multilingual Metters.

7. Chang, C. P \& Shu, (2000) the experiment research for English teaching with small class of junior high school (the ministry of Education the 2000 academic year research project of taiasan high school technician conference).

8. Chang, L.U (2000) Communicative language teaching: senior High school English teachers Belief and practice. Unpublished master theies tamkang university.

9. Clement, R. \& dornyei, Z. \& Noels, K. A. (1994) motivation, self confedence and group cohesion in the foreign language classroum language learning, 44 (3),417-448.

10. Clement, R. \& kruiclenier, B. G. (1985) orientations in second language Acquistion: the effects of ethnicity, milieu and target language on their emergence language learning 33 (3) 273-291.

11. Crookes, G \& Schmidt, R (1991) Motivation: Reopening the Reseurch Agenda, language learning 41 (4), 469-512.

12. Dornyei, Z. (1994) motivation and motivating in the foreign language classroom. The modern language journal, 78,273-284.

13. Dornyei, Z. (2001). Teaching and Researching motivation. England: Pearson Education Limited.

14. Dornyei, Z. (2005) the psychology of the language learner: individud differences in second language acquisition lawaence Erlbaum Associates luc. Mahwah: New Jersey. 


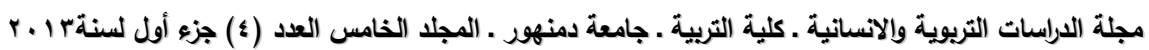

15. Dossari, M.N. (1990) ESP textbook design: one evaluation, llupublished master thesis, Indiana state university.

16. Ellis, R. (1985), (1997) underst-tanding second language Acquistion. Oxford: Oxford university Press.

17. Gardener, R.\& lambert, w (1972) attitudes and motivation in second language learning Rowley mass: Newbury House.

18. Garderer, R.C\& lambert, W.E (1972) Attitdes and motivation in second language learning Rowley, MA: Newbuiy House.

19. Gardner, R. C.\& maclntyre, (1993) on the measurement of affective valiables in second language learning language 43, (2) 157-194.

20. Gardner, R.C \& et al (2004): integratinre motivation changes duing a year- long intermediate level language course language learning 54 (1) , 1-34 doi: 10.1111/ j. 1467 - 9922. 2004. 00247.

21. Gardner, R.C. \& Lysynchuk, L.M. (1990). The Role of Aptitude, Attitudes, Motivation and Language Use on Second Language Acquisition and Retention. Canadian Journal of Behavioural Science, Vol. 22, 254-270.

22. Gardner, R.C. (1985) souial psychology and second language learning. Rowely MA: Newbury House.

23. Hsieh, Y.T. (2002): A study of the adults' motivation toward the participation in English learning chia-yi, Taiwan: National chung cheng university.

24. Kormos, J\& Dornyei, Z. (2004). The interaction of linguistic and motivational valiables in second language task performance. Retrived from: http//zif.spz.tudramstadt.ed/jg009-2/beitrag/kormos 2. Htm.

25. Kormost, J\& Csizer, K (2010) A compauson of the foreign language learning motivation of hunglinan dyslexic and nondyslexic students international journal of applied linguistcs, 20,2, 232-250.

26. Krashen, S. (1981) second language Acquistion and second language learning Oxford: Pergamon.

27. Kubanyiova, M (2006) developing a motivational teaching practice in EFL teachers in Slovakia: chalerye of promoting teacher change in EFL contexts. The electronic journal for English as a second language, 10 (2). Retrieved from: http://testej.org/ej38/a5.html 
28. Liu, M. (2007). Chinese Students' Motivation to Learn English at the Tertiary Level, Retrieved from http://www.asian-efljournal.com/march-07-ml.php.

29. Liuoliene, A\& metiuniene, R (2006) second language learning motivation. Edukologija, vol. 14, lvo.2, 93-98.

30. Luckmani, U.M. (1972). Motivation to Learn and Language Proficiency, Language Learning, Vol. 22, 262-273.

31. Mallah, S. (2000). English in an Arabic Environment: Current Attitudes to English among Kuwait University Students. International Journal of Bilingual Education and Bilingualism, Vol. 3, No. 1, 19-43.

32. Metiuniene, (2006) motivating students in the EFL classroom canadion center of www.ccsent.org/journalindex.../8333retrievedjan 17, 2011 doi: $10.5539 /$ eltv4n3p33.

33. Moss, D. \& Ross, Feldman, L (2003), (2004). Second language acquoition in adults: from research to practice. Retrieved from: http//www.cal. org/caela/es/resourses/digests/SLA.html.

34. Obeidat, M. (2005). Attitudes and Motivation in Second Language Learning. Journal of Faculty of Educ. Hashemite University.

35. Oller, j.w. et al (1977a) attitudes and attainded proficiency in ESL: A socil-linguistic study of native speakers in chines in the united state language learning, 27-1-27.

36. Olshtain, E. et al (1990): Factors predicting success in EFL Among cultrally different learners language leaving vol.40, 23-44.

37. Oxford, R.,\& shealim (1994) language learning motivation: expanding the theoretical framework modern language journal, 78 (1), 12-28.

38. Pintrich, P.R. et al (1994): classroom and individual differences in Early Adolescents motivation and self regualated learning. Journal of Early adolescen ce, 14 (2), 139-161.

39. Rueda, R., \& Chen, C.Y.B (2005): Assessing motivational factors in foreign language learning: cultural valiation in key constructcs. Eduacational Assessment 10 (3) 209-229.

40. Smith, R.M. et al (1978) Evaluating educational environments Columbus OH: C.E. Merrill Pub. Co.

41. Spolsky, B. (1988). A general theory of second language learning TESOL Quastesly, 22 (3), 377-396.

42. Stern, HH. (1992) issues and options in language teaching oxford England: oxford university press. 


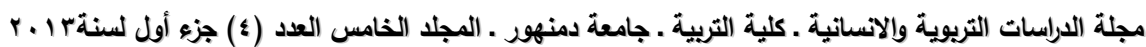

43. Sturgeon, c.m. (2008) aptitucle atlitude, and motivation: as predictors in foreign language learning retrieved from $\mathrm{http} / / \mathrm{www}$.scribed.com/doc/4/31125/inteinsic- motivation. Language- learning lit reviewi.

44. Svanes, B. (1984) motivation and cultural distance in second language acquisition. Language learning, 3, 341-359.

45. Tabatabaei, O.\& Bandau, M. (2012) Iranian EFL learners' attitudes towards the use of computer mediated power point presentations. Theory and practice in language studies, vol. 2, No.2, pp.214-223.

46. Thanasoulas, D. (2001). Constructivist Learning, The Weekly Column, Article 54, April.

47. Thanasoulas, D. (2002): motivation and motivating in the foreign language classroom, the infernet TESL journal, akasa 74 (at) hotmail.com, www.geotities.com/glossologos/

48. Ushioda, E. (1997). The Role of Motivational Thinking in Autonomous Language Learning. In Little, D. and Voss, B. (Eds) Language Centers: Planning for the New Millennium, Plymouth: University of Plymouth CERCLES, Center for Modern Languages, 39-50.

49. Voget, C. \& Oliver, D. (1999). Kuwait University, Faculty of Medicine, Students' Attitudes towards English and an English Based Curriculum. Almanakh, 8 (1), 9-17.

50. Wright, T. (1987). Roles of Teachers \& Learners. Oxford: Oxford University Press. 
